\title{
Impact of Knowledge Sharing and Leakage on Innovative Performance
}

\author{
Mohammad J Adaileh ${ }^{1}$ \& Hasan Z Abu AlZeat ${ }^{1}$ \\ ${ }^{1}$ College of Business and Economics, Qassim University, Qassim, Saudi Arabia \\ Correspondence: Mohammad J Adaileh, College of Business and Economics, Qassim University, Qassim, Saudi \\ Arabia. E-mail: mohd28112001@yahoo.com; m.adaileh@qu.edu.sa
}

Received: November 22, 2016

Accepted: December 21, 2016 Online Published: February 3, 2017

doi:10.5539/jsd.v10n1p92

URL: http://dx.doi.org/10.5539/jsd.v10n1p92

\begin{abstract}
Organizations share knowledge in order to achieve its strategic objectives and enhance innovative performance, most important business process and critical knowledge are subjected to unwanted leakage. This study focused on the aspects and concerns associated with knowledge sharing within and outside organizations. To achieve this objective, the study construct, validate, and test the structure equation modeling for knowledge sharing, knowledge leakage, and innovation performance. A survey was designed and the data were collected in 2015 from managers and owners of 600 industrial companies in KSA. The total responses were 276. Confirmatory factor analysis was used to validate the constructs, then subjected to structure equation modeling to test hypothesis. Model fit parameters indicated normal fit and suitability as the research model. Finding indicated that knowledge leakage negatively mediate the positive impact of knowledge sharing on innovation performance, and some of leakage may be beneficial and have a positive impact, especially when sharing knowledge with customers and competitors in order to develop market innovation. Theoretical implication supplement few empirical studies that shown knowledge leakage as mediator leads to minimize positive results of knowledge sharing. Since KSA recently began the transition to knowledge economy, where much of knowledge sharing occurs dramatically, the study provides analytical framework for Managerial and practical implication about important aspects of knowledge sharing, the method and measures proposed by this study allow organizations to map, formalize and measure their knowledge activities, model can be applied in corporate level to identify the specific impact among organizational units and company's networks.
\end{abstract}

Keywords: knowledge sharing, knowledge leakage, innovation performance

\section{Introduction}

Theoretical applied studies focused on the role of knowledge sharing across the supply chain to get the significant results for the organizations. In the literature of organizational learning, studies did not focus only on ways to transform existing knowledge, but also on how to create new knowledge (Hardy et al, 2003). Studies related to networks indicated that organizations that collaborate and share knowledge with other parties within the supply chain has been able to change its strategic location. Thus, we found many organizations that owns a variety of networks across various industries usually has many advantages due to their access to rich knowledge bases (Rosenkopf and Almeida, 2003). Organizations usually need to share some knowledge that possess in order to access external knowledge, which could contribute to develop their innovation capabilities, they consider this as essential part of business transactions (Barachini, 2009). However, the organizations that share knowledge externally also face unwanted knowledge leakage risks. The leakage of most important business process is the biggest obstacles that prevent knowledge sharing and collaboration (Martinez-Noya et al., 2013). Many recent studies in knowledge sharing have focused on the negative aspects and concerns associated with the participation of knowledge, attributable to the effects of indirect leakage of knowledge and the cost associated with that leakage (Casimir et al., 2012; Foss et al., 2010; Husted and Michailova, 2010). Strategically, many studies have been conducted to explore and clarify the reasons that make the collaboration across supply chain facilitating participation in various resources including knowledge. Many indicated that there are difficulties and obstacles exist when the development of knowledge internally (Christensen and Bower, 1996; Levitt and March, 1988), which makes accessing to external knowledge essential. Lots of studies have pointed to the importance of internal knowledge sharing in order to access external knowledge sources (Chao, et al, 2010). This study focuses 
on investigating the impact of knowledge sharing across the supply chain on the innovative capabilities (Innovative Performance), considering the role of knowledge leakage of significant business process in organizations. The significance of the study comes from studying the innovation environment that has become more complex and intertwined, which imposed innovative organizations to get the knowledge they need from outside its borders (Duysters and Lokshin, 2011; Spithoven et al., 2010). Since the inter-organizational exchange of knowledge and resources help organizations take advantages of the integration of knowledge and specialization, as a result increase the innovative capacity (Dhanaraj and Parkhe, 2006), but the benefits achieved may be limited due to the leakage of knowledge. Compared to the researches in internal knowledge sharing, studies in the field of external knowledge sharing are not mature yet. Partially, the reason is that external sharing of knowledge is not considered among the core activities of the organization. Many studies in the field of knowledge and supply chain management have been reviewed, most of them have agreed upon the idea that accessing and sharing of knowledge are often a prerequisite for innovation within the organizational context (Kogut and Zander, 1992; Sáenz et al., 2012). Lack of studies deal with the negative impact of knowledge sharing internally, and externally. This study focuses on the following question: What is the impact of knowledge leakage on innovative performance at the corporate level. The study focuses on investigating the role of both internal and external knowledge sharing in innovative performance under the influence of business knowledge leakage as a mediator factor. The significance of this study comes from being one of the first studies in the subject of knowledge leakage as a mediator factor affecting sharing of knowledge across supply chain. The study developed a questionnaire to measure this relationship based on many reliable and validated measurement tools used in previous studies. Additionally, the study is significant because it trying to deepen the understanding of knowledge leakage as a mediator between knowledge sharing and innovative performance. As the knowledge leakage is a source of concerns for many organizations, the study providing new evidence that knowledge sharing may have a negative impact on the overall performance and the innovative performance in particular. The study will help organizations identify and allocate resources to deal and avoid the loss of knowledge assets. A general framework for this study has proposed, with reference to the literature in order to develop hypotheses for the three selected dimensions (knowledge sharing, knowledge leakage, and innovative performance).

\section{Theory and Hypothesis}

The framework and hypotheses indicate that positive innovative performance is related to internal and external knowledge sharing at the corporate level, we developed the intermediate hypothesis in the study, which indicates $"$ the leak of knowledge negatively effects a relationship between the internal and external knowledge sharing and innovative performance as shown in figure (1).

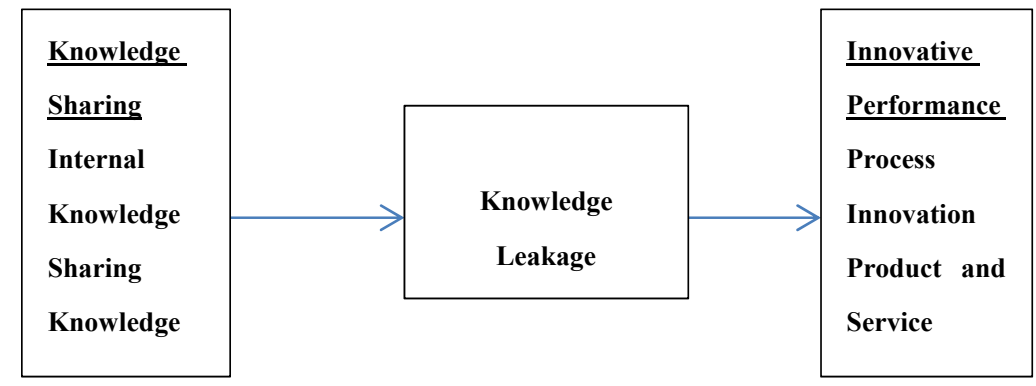

Figure 1. The study framework

Researchers consider sharing knowledge as a source of innovation and value creation, both internally or external (Dhanaraj and Parkhe, 2006; Al-Tit, 2016A). Knowledge sharing is also precedent to innovative performance because innovation is inherently connect the external cognitive components (Huizingh, 2011). Lots of evidences indicate that internal knowledge sharing across organizational unit provide competitive benefits (e.g. Gupta and Govindarajan, 2000; Schulz, 2001). Internal knowledge sharing refers to the process through which individuals, teams, units, exchange, receive and influenced by the experience and knowledge of others (Argote et al., 2000). Internal and external knowledge sharing are both have important implications for organizational performance and innovativeness. Prior researches support that positive relationship and contribution to the development of organizational capabilities (Lyles and Salk, 1996; Steensma and Lyles, 2000). Many researchers focused on how knowledge sharing relates to innovativeness, for example, Powell et al (1996) and Tsai (2001) studied how internal knowledge sharing enables an organization to create new ideas for new product development. It has been recognized that sharing of knowledge internally associated with many challenges, these challenges become even 
more important when the organizations participating knowledge externally (Ding et al., 2013).It is not surprising that there are critical differences in the way the knowledge sharing is managed, either internally or externally (Chesbrough, 2007).

Choi et al (2010) developed a scale to measure employee engagement in knowledge sharing internally, as well as with different kinds of knowledge which are shared with external parties, he concluded that sharing knowledge affects the creative capacity both internally and externally. According to Cohen and Levinthal (1990), acquiring knowledge from externals not only permits more efficient utilization of related knowledge but also enables organizations to better understand and evaluate the nature and commercial potential of technology. The study of Zellmer-Bruhn (2003) and Chesbrough (2003b) indicated to excellent opportunity for external knowledge sharing in helping to discover and investigate the potential of that knowledge and potential markets, increasing the company's attractiveness as a collaborative partner with a high potential for innovation in intra projects. Gupta and Polonsky (2014) indicated to strategic location and increase innovative capabilities in operations, then increase the innovative performance as long as the organization relies on the knowledge and capabilities that have not been developed internally. Knowledge sharing is desirable behavior and expected to achieve strategic goals through cooperation and innovation. Knowledge leakage is in stark contrast, it is undesirable behavior by employees who share the knowledge that the organization would like to keep it internally. The staff may disclose more than required to their colleagues in the participating organizations because of poor oversight of the cooperative environment between the organizations, or when they disclose their designs and new products and processes without thinking. This could happen in formal and informal occasions and professional exhibitions. And also, it can be caused by enthusiasm for new idea or potential innovation, or when increasing confidence, they will keen to share knowledge (Van den Hooff et al., 2012; Sié and Yakhlef, 2009).Based on the above, the leak of knowledge negatively affect the pros realized from the exchange of knowledge in their impact on innovative performance. Organizations don't want to participate in any thing with collaborative partners, this can lead to disable accessing to the benefits of innovation. The individuals in the cooperative façade are the actual people who influence the success of knowledge exchange activities and influence the ultimate innovative performance in the organization as a whole (Hannah, 2005). Theoretical review revealed five external parties organization can cooperate with the, where the organization can share knowledge and new ideas for innovation. The organization can allow these parties access to information and knowledge of their own (Laursen \& Salter, 2006; Lichtenthaler,2011). Those five parties are (customers, suppliers, competitors, universities, and independent experts as studied by Belderbos, Carree \& Lokshin (2004).

Knowledge sharing with competitors is controversial, sharing of knowledge with customers is positive in product development (Steinhoff \& Trommsdorff, 200, Al-Tit, 2016b). Also, the exchange of knowledge with suppliers, universities and research institutions have a significant impact in the development of innovative products, processes, and market (Primo \& Amundson, 2002). In this study, we focused on two of these potential sources of knowledge, customers and competitors because they relate directly to innovative performance in products, processes, and market. Sharing knowledge with customers is one of the most important relationships in the study framework because customer can help organization obtain new ideas about product and solutions (Urban \& Von Hippel,1988), while sharing knowledge with competitors is likely to lead to negative consequences for the innovative performance, as it is controversial (Segarra-Blasco \& Arauzo-Carod, 2008). According to Teece (2006), despite the fact that companies may refrain from knowledge sharing externally because of the potential risks for leakage of knowledge, but that may lead to an advantage to achieve innovation in performance at the operational level. So, the strong competition in the knowledge markets push companies to share knowledge externally. If the organization did not participate knowledge externally, they will not be able to achieve the benefits of its strategy, and also lose access to external knowledge, and knowledge will remain unused.

\subsection{Knowledge Sharing with Customer}

Sharing knowledge with customers is one of the most relationships that studied in the framework of the development of innovation performance (Urban \& Von Hippel,1988). It helps in the product and market development (Tether, 2002). The customer's involvement in the early stages of product design helps to solve many problems related to design, as well as on the process of providing the product (Faems, Van Looy \& Debackere, 2005). As a result, customer engagement can lead to innovation in the product, this was confirmed by many researchers. But others have found that there is a negative relationship to share knowledge with customers on innovative performance (loof \& Heshmati, 2002; Knudsen, 2007), particularly with regard to innovation in the product, and the market. For example, Bonner and Walker (2004) found that Customer is unable to conceptualize ideas for improvement because of the lack of experience. Nieto and Santamaria (2007) remark that firms that concentrate too heavily on customers run the risk of losing knowledge to other parties. We assume that 
the positive aspects of customer involvement in knowledge sharing outweigh the negative ones.

\subsection{Knowledge Sharing with competitors}

As stated above, knowledge sharing with competitors is considered controversial. But it can help to the consolidate knowledge in order to accelerate the company's development capabilities and reduce the time and cost required to develop the product for both company and competitor. This kind of knowledge sharing can help also firms benchmark its technological capabilities with competitors, thus differentiate itself by creating areas that find itself a strong and offer different products rather than imitate competitors' products (Tether, 2002). There are many risks for knowledge sharing with competitors, for example transferring sensitive knowledge to competitors, so the company must balance carefully between the benefits and risks of sharing knowledge with competitors. Many studies have pointed at conflicting results, for example, Loof and Heshmati (2002) indicated to positive impact on products sales. But Cassiman \& Veugelers (2002) have indicated this relationship is insignificant. We can't ignore existence of a relationship between the exchange of knowledge with competitors on innovative performance despite the controversial results in literature, we focused on the impact of knowledge sharing with competitors on innovative performance, in addition, how knowledge sharing with competitors can lead to leakage of knowledge. We argue that the flow of knowledge outside and leakage occurs when there is an internal knowledge sharing between members of the organization and when organization share knowledge with external parties (customers, competitors). This leads us to first group of hypothesis:

\section{Hypothesis 1.}

Hla: knowledge leakage is positively associated with internal knowledge sharing.

H1b:knowledge leakage is positively associated with knowledge sharing with Customers.

H1c:knowledge leakage is positively associated with knowledge sharing with competitors.

\subsection{Innovative Performance}

Reviewing the literature in the field of innovation demonstrate that most of the studies identified five dimensions for innovative performance namely: Innovation in processes, innovation in products and services, market innovation, innovation behavior, and finally strategic innovation. Many researchers identified different dimensions of innovation. For example, Schumpeter (1934) proposed possible alternatives for innovation, such as the development of products and services, the development of new methods of production, identify new markets, discover new sources of supply, and the development of new organizational models. Miller and Friesen (1983) focused on innovation in new products and services, innovation in production methods for providing of services, taking risks. The study used three dimensions including innovation in processes, innovation in products and services, innovation in the market due to its direct proximity to the activities of the supply chain. Process innovation was used in this study, which related to provide new methods of production, modern management methods, modern techniques that can be used to improve the production and management processes. Innovation in processes is imperative in general innovative capabilities, in terms of the organization's ability to exploit its resources and capabilities, and more importantly, the ability to re-assemble and configure resources and capacities to meet the inventive production requirements, and is considered so critical to achieve organizational success (Lyon et al, 2000). Researchers did not address the innovation in processes clearly, the study of both Kitchell (1997) and Avlonitis et al. (1994) considered innovation in processes as a sub-element of technological innovation. They also considered that technological innovation are linked to innovation in machinery and production methods as tools for technological innovation. Within this perspective, the technological innovation is embodied in each of the innovation in new products that include a unique and modern technological content.

According to innovation in products and services, based on previous studies - the definition of innovation in the product in this study is as a novelty and significance of the new products offered to the market at the right time, where this definition distinguishes innovation in the product from other types of innovation. Danneels and Kleinschmidt (2001) considered innovation in the product is prior to success of product, and linked to successfully business. Since the innovation in the product provides a great opportunity for businesses to grow and expand into new areas. Important innovations allow to build a competitive advantage in the markets, and provide an opportunity for new entrants to gain a niche in the market. Danneels and Kleinschmidt (2001) integrates two perspectives of product innovation, First, from the consumer's perspective, features such as the characteristics of innovation, embrace risk, and levels of change in behavioral patterns recognized. Second, from the company's perspective, environmental considerations, appropriateness with the company's projects, technological and marketing aspects are all dimensions of innovation in the product. Innovation in the market refers to the modern methods adopted by the companies in order to enter and take advantage of the target 
markets. Under all circumstances, the company will face new competition both in new and current markets. While product innovation focuses on renewal, innovation in market focuses on modernity in the market-oriented approach. despite the separation of them, the dimensions are sometimes intertwined (Wang, Ahmad, 2004). Ali et al (1995) argue that innovation in the market is associated significantly to innovation in the product. They define innovation as uniqueness or novelty of the product in the market. From the broader perspective, innovation in the market refer to the innovation associated market research, advertising and promotion, as well as identifying new market opportunities and access to new markets.

As the knowledge sharing is essential to the achievement of innovation, sharing knowledge with external partners leads to loss of important knowledge of the organization, Examples include trade secrets, basic techniques, and other types of strategic knowledge (Dhanaraj and Parkhe, 2006; Hannah, 2005). Ahmad et al (2014) studied the negative effects of knowledge leakage on various companies, leak of knowledge lead to loss of revenue, destruction of reputation, productivity reduction and arising confidentiality agreements breached costs, reduce the bargaining power, and so. It also leads to the creation of new competitors for owner of original knowledge, so when employee leaking knowledge, which is rare, the recovery from this situation is a challenge. Study of Hurmelinna-Laukkanen and Olander (2014) indicated that the strength and ability of the partners or competitors to absorb knowledge assets affect the degree of damage from leakage. In case of working with a partner who has a high capacity to absorb knowledge, the company is losing the advantages of knowledge assets, the resulting fear for competitors to imitate the company's innovations hinders investment in research and development and therefore innovation. Such practices put the organization to a difficult situation of losing the benefits and values of knowledge represented in new innovations in products and processes. Infusion may happen deliberately and serves certain goals. Although organization may leak some existing knowledge in order to achieve some gains in the markets, for example, leaking some information about the product will be launched soon in the market to create more publicity and increased anticipation. This is a strategic marketing decision. Leak of knowledge may be considered wrong behavior when it is deliberated to harm company (Hoecht and Trott, 2006). This mean that firm faces leakage of sensitive knowledge will not gain innovation benefits from knowledge sharing. Thus we formalize the second group of hypotheses as follow:

\section{Hypothesis 2.}

H2a: knowledge leakage is negatively affect process innovation.

H2b:knowledge leakage is negatively affect product and service innovation.

H2c: knowledge leakage is negatively affect market innovation.

Despite the benefits of sharing knowledge internally, sharing knowledge with customers, and sharing knowledge with competitors on innovative performance (Rosenkopf and Almeida, 2003; Barachini, 2009; Kogut and Zander, 1992; Sáenz et al., 2012), this exchange means there is a potential leak in the sensitive Organizational knowledge to other parties (Martinez-Noya et al., 2013; Casimir et al., 2012; Ahmad et al, 2014), accordingly, this leakage will harm and negatively affect the positive impact of knowledge sharing on innovation performance (Process, product and service, and market). We formalize the arguments in the following last group of hypothesis:

Hypothesis 3.

H3a: knowledge leakage negatively affect the positive impact of internal knowledge sharing on process innovation

H3b: knowledge leakage negatively affect the positive impact of internal knowledge sharing on product and service innovation

H3c: knowledge leakage negatively affect the positive impact of internal knowledge sharing on market innovation

H3d: knowledge leakage negatively affect the positive impact of knowledge sharing with customers on process innovation

H3e: knowledge leakage negatively affect the positive impact of knowledge sharing with customers on product and service innovation

H3f: knowledge leakage negatively affect the positive impact of knowledge sharing with customers on market innovation

H3g: knowledge leakage negatively affect the positive impact of knowledge sharing with competitors on process innovation 
H3h: knowledge leakage negatively affect the positive impact of knowledge sharing with competitors on product and service innovation

H3i: knowledge leakage negatively affect the positive impact of knowledge sharing with competitors on market innovation

\section{Method}

\subsection{Sampling}

All industrial companies in the Kingdom of Saudi Arabia was chosen. This sector is related to operations of production and market, products and services, and often these companies manage their activities through supply chain, which requires collaboration and integration on the highest level, and would entail exchange of information and expertise for the success of integration within the supply chain. The size is too large and characterized by heterogeneity and rapid development, it also extends over the entire geographical area. Due to increasing pressure on companies towards becoming a knowledge-based economy and diversify sources of income, and because companies depend on the exchange of knowledge dramatically in production and innovation, it was inevitable to direct studies to highlight the problems facing knowledge exchanging in this the sector. Companies in which the number of employees is more than 50 employees has been selected, the reason is because knowledge-sharing opportunities grow larger when number of employee increase. Data were collected through a survey using the tool tested by a group of managers and academics to check their validity, clarity and readability. The questionnaire was sent to a sample survey by e-mail or interview people directly. Sample include executives, organizational units managers, operations managers and staff, in addition to the owners. Lists of companies was obtained through chambers of commerce and websites. We selected an appropriate sample of 600 industrial companies from different areas in the Kingdom including Jeddah, Qassim, Riyadh, Dammam. Questionnaire has been sent to them and recalled 276, all of them were valid for analysis. The reason for the low response rate $(46 \%)$ since the study focused on a small group of employees of managers and owners of companies. There is little response in other surveys have focused on managers, such as the study of (Byrd and Turner, 2001; Wisner, 2003) where the response rates asymptotic to this study. Despite the low response rate, the responses from the managers and owners of companies can be considered valuable and provide insight as previous studies indicated. Questionnaires data was analyzed, and Table 1 shows the characteristics of the study sample.

Table 1. Survey respondent profile

\begin{tabular}{lcc}
\hline Title & Frequency & Percentage \\
\hline CEO & 38 & $14 \%$ \\
President & 52 & $19 \%$ \\
Vice & 65 & $24 \%$ \\
President & & $26 \%$ \\
Director & 72 & $18 \%$ \\
Senior & 49 & \\
Manager & $\underline{276}$ & \\
Total & $\mathbf{2 7 6}$ & \\
Firm Size & & $29 \%$ \\
$50-100$ & 81 & $27 \%$ \\
$101-251$ & 74 & $21 \%$ \\
$251-500$ & 57 & $8 \%$ \\
$501-1000$ & 43 & \\
$1000+$ & $\underline{21}$ & \\
Total & $\mathbf{2 7 6}$ & \\
\hline
\end{tabular}




\subsection{Measurement Tool}

Measurement tool was developed to measure the impact of three independent dimensions of this study (internal knowledge sharing, sharing knowledge with consumers, sharing knowledge with competitors) on innovative performance (process, products and services, and the market), knowledge leakage mediate this relationship. The development of measurement tool followed three phases, a theoretical review in order to generate the paragraphs and setup the initial paragraphs, then conducted interviews with a selected group of academics, experts and practitioners in the industrial sector for the initial evaluation of the validity and credibility, and finally the survey to check the reliability. Theoretical review aimed to ensure the validity of the measurement content, such as several studies in the field of knowledge sharing within the supply chains, as well as innovative performance studies. A comprehensive review of the study construct has been conducted, then the development of the proposed initial paragraphs, it was offered on a selected sample of managers in companies, chosen two companies Qassim region, namely (Dove Pharmaceutical Company, Qassim Cement Factory) in order to assess the credibility of the measure and ensure the clarity and relevance for each paragraph, as well as the order of the paragraphs based on priority for the measurement of that dimension, then classified by harmony of each paragraph with construct, based on their observations, some duplicated and unclear paragraphs removed, then edited others and add some paragraphs when necessary. Six managers has been interviewed to ensure measurement tool conformity with the surrounding environment. We sent the Questionnaire to five academics in the departments of management information systems, production management and business administration in the University of AL-Qassim, and King Abdulaziz University, where they review each paragraph of the scale, we modified, added, removed, moved some paragraphs for each dimension based on their feedback.

A total of 39 items were generated from literature to measure seven constructs, internal knowledge sharing and based on studies (Faisal et al. 2007; Zhao et al. 2002; Choi et al., 2010), the scale included three paragraphs. Knowledge sharing with consumers has depended on the studies of (Simatupang and Sridharan 2005), (Freel, 2003; Faems, Van Looy \& Debackere, 2005) and included three paragraphs, too. We depended on studies of (loof and Heshmati 2002), (Cassiman \& Veugelers, 2002). (Belderbos, Carree \& Lokshin, 2004; Tsai, 2009) for the development of knowledge sharing with competitors scale and included five paragraphs. Knowledge leakage construct has included a 11 paragraph and based on studies of (Ritala et al, 2015; Tan et al, 2015). Innovative performance paragraphs were adopted from studies of (Kitchell, 1997; Avlonitis et al. 1994; Zirger, 1997; Sethi et al., 2001; Andrews and Smith, 1996; Schumpeter, 1934; Cooper, 1973; Miller, 1983), and consisted of three constructs, innovative performance in operations and include six paragraphs, five paragraphs for innovative performance in products and services, and finally six paragraphs for the innovative performance in the market, see Annex ( A) for final questionnaire items. Seven-Likert scale for all the paragraphs was used to answer paragraphs as follows (7-Strongly Agree, 6-Agree, 5- I agree a little, 4-Neither agree nor disagree, 3-Disagree, 2A little disagree, 1-Strongly disagree). The first part is for demographic characteristics of the sample and included business type, number of employees, and job location.

\subsection{Data Analysis}

Confirmatory Factor Analysis (CFA) were used to validate the construct (Byne, 2001). A total of 276 cases were processed using AMOS 16.0, Maximum Likelihood (ML) estimation method used, our sample size is reasonable to use this method of estimation, and the scale of observed variable is continuous and multivariate normal. The normality of observed variables were tested, according to west et al. (1995) for sample size of 200 or less, univariate skewness $<2$, univariate kurtosis $<3$ is acceptable, this assumption was met as the univariate skewness for each variable is $<0.937$ in absolute value, and the univariate kurtosis of each variable is $<1.162$ in absolute value. Raykov and widaman. (1995) also indicated that ML estimation method can be used for data with minor deviation from normality. Many researcher has identified CFA as an appropriate statistical test particularly when a number of factors required to explain inter-correlations among the measurement variables (Sureshchandar et al. 2002). Additionally, the observed variables that were more likely to be reliable indicators of a particular factor (Sureshchandar et al. 2002). Our model was based on logic, previous empirical research and theoretical findings. The CFA would be appropriate method to confirm the proposed factors of knowledge sharing and leakage, and innovation performance. Analysis of first- order measurement model for all construct were conducted. All 39 item generated included, the initial model fitness was assessed and re-specified, then CFA was performed based on the re-specified model. Finally the model were reported as accepted measurement model after benchmarking with five another models. The consistencies of data and theoretical framework are accountable when evaluating each item. Also over- identified model was produced, by fixing the first regression path in each measurement component at 1 , the criteria used is item's error variance. As indicated by large modification indices, evidence of items needed to cross- load on more than one component factor. The extent to which items give rise to 
significant residual covariance, parsimony, purpose, regression coefficient of each item. Reliability of the item and construct.

\section{Results}

\subsection{First Order CFA}

The first model fit indices were $\mathrm{x} 2=874.046, \mathrm{df}=366, \mathrm{x} 2 / \mathrm{df}=2.338, \mathrm{GFI}=0.696, \mathrm{AGFI}=0.701$, RMSEA $=0.70$, PCLOSE $=0.000, \mathrm{PGFI}=0.684, \mathrm{NFI}=0.781, \mathrm{CFI}=0.811, \mathrm{RMR}=0.161$. theses indicated the need to re-specify the original model to fit sample data better. Following, modification were made to improve model: First model, which contain 39 items showed that knowledge leakage items KL3, KL5, KL9 had poor square multiple correlation (Respectively $0.13,0.10,0.16)$, as well low regression weights $(0.33,0.29,0.31)$, those items were deleted. Item KL10 of knowledge leakage cross-loaded onto other factor which is KL2 (M.I= 4.657), and KL8 (M.I = 5.188). item KL10 were eliminated to avoid cross loading. Items PSI2, MI1 had larger error covariance (42.749), and the square multiple correlation of item MII was 0.58 , and 0.61 for item PSI2. Also regression weight for item MI1 was 0.77 while regression weight for item PSI2 was 0.79 . This indicated that item MI1 has less effect, thus it was deleted. Error variances were examined, the error variance for items $\mathrm{KSCO} 5=1.55$, $\mathrm{KL} 2=$ 1.53 , MI4 $=1.44$, MI6 $=1.49, \mathrm{PSI} 3=1.17, \mathrm{PI} 4=2.08, \mathrm{MI} 5=2.05, \mathrm{KL} 8=1.85$. While these items did not significantly affect other items, they were eliminated. Finally we retain items KSCO3, PSI4 despite they had low regression weight $(0.46,0.43)$, and low squared multiple correlation $(0.19,0.21)$. removing them will cause other items to lose their overall effect on the component factor. Also removing them would have weakened reliability value of the knowledge sharing with competitors and product and service innovation. Although the overall goodness of fit indices improved, we retain some items even of large error variance because if we delete them, it may cause other items to lose effect on component factor and overall model fit. Based on the above analysis, 13 items were eliminated. Table (2) show that regression weights for all variables loading to their factors are between 0.43 and 0.92 with all critical ratio above 1.96 which means that all regression are statistically significant at $95 \%$ confidence level. Table (2) show also the modified first order CFA model fit indices, and the covariance between any two of these component factor, and the critical ratio (note that the critical ratio for first variable in each component factor is not available because regression weight is fixed at 1.

Table 2. First- order confirmatory factor analysis

\begin{tabular}{|c|c|c|c|c|c|c|c|c|}
\hline \multirow[b]{2}{*}{ Variable } & \multirow[b]{2}{*}{ R-Squared } & \multicolumn{7}{|c|}{ Standardized Loading } \\
\hline & & $\begin{array}{ll}\text { Internal } & K . \\
\text { Sharing } & \end{array}$ & $\begin{array}{l}\text { K. Sharing } \\
\text { with Customer }\end{array}$ & $\begin{array}{l}\text { K. Sharing With } \\
\text { Competitors }\end{array}$ & K. Leakage & $\begin{array}{l}\text { Process } \\
\text { Innovation }\end{array}$ & $\begin{array}{l}\text { Product } \\
\text { Service } \\
\text { Innovation }\end{array}$ & $\begin{array}{l}\text { Market } \\
\text { Innovation }\end{array}$ \\
\hline Internal K. Sharing & & & 0.77 & 0.69 & 0.85 & 0.7 & 0.77 & 0.87 \\
\hline IKS1 & 0.88 & 0.71 & & & & & & \\
\hline IKS2 & 0.90 & $0.74(8.409)$ & & & & & & \\
\hline IKS3 & 0.74 & $0.57(5.270)$ & & & & & & \\
\hline K. Sharing with & & & & & & & & \\
\hline Customer & & & & 0.68 & 0.88 & 0.69 & 0.74 & 0.84 \\
\hline $\mathrm{KSC} 1$ & 0.39 & & 0.73 & & & & & \\
\hline $\mathrm{KSC} 2$ & 0.44 & & $0.92(13.862)$ & & & & & \\
\hline $\mathrm{KSC} 3$ & 0.76 & & $0.49(6.408)$ & & & & & \\
\hline K. Sharing With & & & & & & & & \\
\hline Competitors & & & & & 0.75 & 0.76 & 0.87 & 0.58 \\
\hline KSCO1 & 0.32 & & & 0.56 & & & & \\
\hline $\mathrm{KSCO} 2$ & 0.55 & & & $0.63(5.184)$ & & & & \\
\hline $\mathrm{KSCO} 3$ & 0.19 & & & $0.46(0.5 .804)$ & & & & \\
\hline $\mathrm{KSCO} 4$ & 0.61 & & & $0.83(9.564)$ & & & & \\
\hline K. Leakage & & & & & & 0.59 & 0.67 & 0.74 \\
\hline
\end{tabular}




$\begin{array}{lll}\text { KL1 } & \mathbf{0 . 3 2} & \mathbf{0 . 7 2} \\ \text { KL4 } & 0.41 & 0.47(6.904) \\ \text { KL6 } & 0.58 & 0.55(5.102) \\ \text { KL7 } & 0.44 & 0.77(8.220) \\ \text { KL11 } & 0.33 & \mathbf{0 . 4 5 ( 6 . 5 6 3 )}\end{array}$

Process Innovation

\section{Product and Service}

Market Innovation

\subsection{Second Order CFA}

All 26 items extracted on first order confirmatory factor analysis are loaded in second order CFA. As can be shown in table (3), the regression weight for all items ranged from 0.79 to 94 with all critical ratio above 1.96 . model fit indices became more stronger and the model improved. The differences in estimation is because of the changing in the degree of freedom in the two models. Model fit indices were $x 2=308.225, \mathrm{df}=169, x 2 / \mathrm{df}=1.823$, $\mathrm{GFI}=0.931, \mathrm{AGFI}=0.883, \mathrm{RMSEA}=0.034, \mathrm{PCLOSE}=0.058, \mathrm{PGFI}=0.847, \mathrm{NFI}=0.891, \mathrm{CFI}=0.932, \mathrm{RMR}=0.104$. Each item in model was loaded into only one factor without any cross loading. Table (3) shows the results of standard second order CFA, regression weight, critical ratio. The table shows also squared multiple correlations R2 for each measurement item, composite reliability, variance extracted for each factor, and Cronbach alpha coefficient to measure reliability and validity. Cronbach's alpha coefficient to ensure reliability of the scale and to ensure internal consistency for paragraphs, paragraphs were all accepted as their coefficient are more than (0.70) (Hair et al, 2010). Cronbach's alpha coefficient was calculated for each factor as shown in the table (3).

Table 3. Second- order confirmatory factor analysis

\begin{tabular}{|c|c|c|c|c|c|c|}
\hline Variable & $\begin{array}{l}\text { Factor } \\
\text { loading }\end{array}$ & $\varepsilon$ & $\begin{array}{c}\text { Regression } \\
\text { Weight/C.R }\end{array}$ & $\begin{array}{l}\text { Composite } \\
\text { reliability }\end{array}$ & $\begin{array}{l}\text { Variance } \\
\text { extracted }\end{array}$ & $\begin{array}{c}\text { Cronbach } \\
\text { Alpha } \\
\text { coefficient }\end{array}$ \\
\hline Internal K. Sharing & & & 0.89 & 0.94 & 0.87 & 0.862 \\
\hline IKS1 & 0.751 & 0.081 & & & & \\
\hline IKS2 & 0.835 & 0.054 & & & & \\
\hline IKS3 & 0.923 & 0.072 & & & & \\
\hline
\end{tabular}


K. Sharing with Customer

$\mathrm{KSC} 1$

$\mathrm{KSC} 2$

$\mathrm{KSC} 3$

K. Sharing With Competitors

KSCO1

$\mathrm{KSCO} 2$

$\mathrm{KSCO} 3$

$\mathrm{KSCO} 4$

K. Leakage

KL1

KL4

KL6

KL7

KL11

Process Innovation

PI1

PI2

PI3

PI5

PI6

Product and Service Innovation

PSI1

PSI2

PSI4

PSI5

Market Innovation

MI2

MI3

MI7
$0.84(9.859)$

0.91

0.84

0.813

0.887

0.926

0.843

0.061

0.056

0.078

$0.79(9.808)$

0.89

0.92

0.841

0.041

0.054

0.066

0.068

0.916

$0.87(10.871)$

0.92

0.91

0.846

0.912

0.081

0.089

0.725

0.772

0.044

0.832

0.071

0.881

0.062

$0.91(13.565)$

0.95

0.96

0.917

$0.862 \quad 0.045$

$0.856-0.053$

0.858

0.078

0.884

0.042

0.785

0.032

0.94 (15.890)

0.92

0.94

0.835

0.055

0.817

0.074

0.854

0.076

0.798

0.086

0.851

$0.85(10.522)$

0.88

0.95

0.876
$0.850 \quad 0.092$

$\begin{array}{ll}0.917 & 0.065\end{array}$

$0.889 \quad 0.076$

$x^{2}=308.225, \mathrm{df}=169, x^{2} / \boldsymbol{d}=\mathbf{1 . 8 2 3}, \mathrm{GFI}=0.931, \mathrm{AGFI}=0.883, \mathrm{RMSEA}=0.034, \mathrm{PCLOSE}=0.058, \mathrm{PGFI}=0.847, \mathrm{NFI}=0.891, \mathrm{CFI}=0.932, \mathrm{RMR}=0.104$

\subsection{Reliability and Validity}

Reliability and validity measurement have been conducted for measurement scale to assure whether it measure what the items and construct are supposed to measure. To measure construct reliability, some statistical outputs can be used such as squared multiple correlations (R2 ) for each measurement items, composite reliability and variance extracted for each factor. According to Holmes-Smith (2001), and Byrne (2001), measurement variables considered reliable when (R2) for each item is greater than 0.5. Table (3) show that the (R2) for second order model for all items are greater than 0.5 which indicated a good reliability. Also Cronbach alpha coefficient, composite reliability and variance extracted were calculated to measure the reliability of each factor, as represented in table 3 . Reliable factor indicator should have composite reliability greater than 0.70 and extracted variance value above 0.5 (Hair et al, 1995). As represented in table (3), all values greatly exceeded the minimum acceptable values and error free, and indicated consistent results. Construct validity was measured using Convergent, Discriminant, and Criterion- related validity to indicate that items of measurement measure the construct (Hair et al,1995). Convergent validity indicates that the relationship between items and the factor is significantly different from Zero. Critical ratio that greater than 1.96 can be considered significant based on the 
level of $\mathrm{p}=0.05$ (Anderson\& Gerbing, 1988). In this study, all of measurement items represent their factor significantly because the critical ratio exceeded 1.96 , thus, all measurement items meet the convergent validity test. Discriminant validity was calculated to measure which the latent variables are different. The average extracted variance of the two constructs should exceed the squared of their correlation (Holmes-Smith, 2001). Average variance extracted, squared correlation for every pairs of factors were calculated. The results presented in table (4) showed that average variance extracted for each latent variables was greater than squared correlation for the same pair, note that the upper level is the average variance extracted, and the lower level is squared correlation for every pair. This indicating that each construct satisfied the discriminant validity and is different from other construct.

Table 4. Average variance extracted for latent variables

\begin{tabular}{|c|c|c|c|c|c|c|c|}
\hline Variable & $\begin{array}{c}\text { Internal K. } \\
\text { Sharing }\end{array}$ & $\begin{array}{c}\text { K. Sharing with } \\
\text { Customer }\end{array}$ & $\begin{array}{c}\text { K. Sharing With } \\
\text { Competitors }\end{array}$ & $\begin{array}{c}\text { K. } \\
\text { Leakage }\end{array}$ & $\begin{array}{c}\text { Process } \\
\text { Innovation }\end{array}$ & $\begin{array}{c}\text { Product and } \\
\text { Service Innovation }\end{array}$ & $\begin{array}{c}\text { Market } \\
\text { Innovation }\end{array}$ \\
\hline Internal K. Sharing & & 0.904 & 0.870 & 0.890 & 0.885 & 0.915 & 0.884 \\
\hline K. Sharing with & & & & & & & \\
\hline Customer & 0.215 & & 0.915 & 0.886 & 0.925 & 0.925 & 0.889 \\
\hline K. Sharing With & & & & & & & \\
\hline Competitors & 0.296 & 0.256 & & 0.824 & 0.914 & 0.861 & 0.859 \\
\hline K. Leakge & 0.245 & 0.119 & 0.258 & & 0.865 & 0.876 & 0.906 \\
\hline Process Innovation & 0.365 & 0.325 & 0.215 & 0.356 & & 0.855 & 0.811 \\
\hline Product & & & & & & & \\
\hline Service Innovation & 0.241 & 0.214 & 0.265 & 0.321 & 0.198 & & 0.845 \\
\hline Market Innovation & 0.231 & 0.255 & 0.14 & 0.256 & 0.235 & 0.314 & \\
\hline
\end{tabular}

The overall confirmatory factor analysis for measurement model demonstrate fit indices within the acceptable criteria, the statistical values of the final measurement model indicated the model fitted well in representing the data. Also, all proposed seven factors ( internal knowledge sharing, knowledge sharing with customer, knowledge sharing with competitors, knowledge leakage, process innovation, product innovation, and market innovation) have showed strong uni-dimensionality, reliability, convergent, discriminant. Thus, knowledge sharing and leakage across supply chain, and innovative performance can be conceptualized as seven structured factors, namely ( internal knowledge sharing, knowledge sharing with customer, knowledge sharing with competitors, knowledge leakage, process innovation, product innovation, and market innovation).The instrument then standardized and used to test the hypothesis.

\subsection{Test of Structural Model}

The test of structural model resulted in the following statistical values: $\mathrm{x} 2=248.164, \mathrm{df}=178, \mathrm{x} 2 / \mathrm{df}=1.39, \mathrm{GFI}=$ 0.94, AGFI $=0.878$, RMSEA $=0.049$, PCLOSE $=0.078, \mathrm{PGFI}=0.914, \mathrm{NFI}=0.942, \mathrm{CFI}=0.923$, RMR $=0.04$. This serves as the basis of evaluation for our hypothesis because overall fit indices for the structural model indicated a good fit. Table (5) summarize the results of standardized direct and indirect effects, and total effects for each construct of our model. Ten paths were directly significant to knowledge leakage, process innovation, product and service innovation, and market innovation, four significant indirect affects, and eleven total significant effects as represented in table (5). 
Table 5. Standardized direct, indirect and total effects of structural model

\begin{tabular}{|c|c|c|c|c|}
\hline Exogenous variable & Endogenous variable & $\begin{array}{c}\text { Standardized direct } \\
\text { effect }\end{array}$ & $\begin{array}{l}\text { Standardized } \\
\text { indirect effect }\end{array}$ & $\begin{array}{c}\text { Standardized total } \\
\text { effect }\end{array}$ \\
\hline & & $\beta(\mathbf{p})$ & $\beta(\mathbf{p})$ & $\beta(\mathbf{p})$ \\
\hline Internal Knowledge Sharing & Knowledge Leakage & $0.65(0.014)$ & & $0.65(0.014)$ \\
\hline Knowledge Sharing With Customer & & $0.41(0.003)$ & & $0.41(0.003)$ \\
\hline Knowledge Sharing With Competitor & & $0.53(0.025)$ & & $0.53(0.025)$ \\
\hline Knowledge Leakage & Process Innovation & $-0.06(0.233)$ & & $-0.06(0.233)$ \\
\hline Internal Knowledge Sharing & & $0.55(0.012)$ & $-0.18(0.03)$ & $0.37(0.02)$ \\
\hline Knowledge Sharing With Customer & & $0.10(0.568)$ & $-0.54(0.0 .84)$ & $-0.44(0.671)$ \\
\hline Knowledge Sharing With Competitor & & $0.21(0.211)$ & $-0.23(0.016)$ & $-0.02(0.859)$ \\
\hline Knowledge Leakage & Product and Service Innovation & $-0.67(0.01)$ & & $-0.67(0.01)$ \\
\hline Internal Knowledge Sharing & & $0.77(0.011)$ & $-0.45(0.289)$ & $0.32(0.013)$ \\
\hline Knowledge Sharing With Customer & & $0.59(0.04)$ & $-0.23(0.051)$ & $0.36(0.04)$ \\
\hline Knowledge Sharing With Competitor & & $0.03(0.691)$ & $-0.52(0.001)$ & $-0.49(0.005)$ \\
\hline Knowledge Leakage & Market Innovation & $-0.44(0.02)$ & & $-0.44(0.02)$ \\
\hline Internal Knowledge Sharing & & $0.29(0.236)$ & $-0.32(0.096)$ & $-0.03(0.854)$ \\
\hline \multirow[t]{2}{*}{ Knowledge Sharing With Customer } & & $0.61(0.012)$ & $0.41(0.011)$ & $1.02(0.006)$ \\
\hline & & & & $0.610 .009)$ \\
\hline Knowledge Sharing With Competitor & & $0.24(0.006)$ & $0.37(0.325)$ & \\
\hline
\end{tabular}

\section{Discussion, Implications, Limitations, and Future Research}

\subsection{Discussion}

Our finding indicates significant relationships between knowledge sharing (internal, with customers, and with competitors) and knowledge leakage, that's mean that companies with high level of knowledge sharing are subjected to leak sensitive knowledge. Researchers have recognized that firms are likely need to share knowledge to acquire new knowledge to support innovation and competitive advantage (Gupta and Govindarajan, 2000) and create new ideas (Tsai, 2001). sharing of knowledge internally associated with many challenges, these challenges become even more important when the organizations participating knowledge externally (Ding et al, 2013). Knowledge leakage can be happened when employee share knowledge among organizational units, Van den Hooff et al. (2012) mentioned many cases in which employee can share and leak knowledge. According to Ritala et al (2015), when firm share knowledge with external parties, there is always a risk of unintended knowledge spillover, they also indicated that firm must share their knowledge with external parties to get their knowledge, on same time, it should consider the potential negative effects of leaking critical knowledge. The first group of hypothesis (H1a, H1b, H1C) are significantly supported. Testing of the second groups of hypothesis ( $\mathrm{H} 2 \mathrm{a}, \mathrm{H} 2 \mathrm{~b}$, and $\mathrm{H} 2 \mathrm{C}$ ) indicating significant and direct negative effect of knowledge leakage on product and service innovation, and market innovation, that is the leakage has a great negative effect on these two variables, while knowledge leakage had less effect on process innovation as this hypothesis was not supported. Although, the effect of knowledge leakage on process innovation is not significant, but the effect is still negative. This corresponds with many studies that have pointed to the negative impact of knowledge leakage on innovative performance. Such studies indicated that firms share their own knowledge but should aware of potential leakage that may harm the innovation capabilities (Ritala et al, 2015). Despite the benefits of knowledge sharing (internally, externally) to innovative performance, firms face many risks and challenges. For example loof \& Heshmati, (2002) and Knudsen, (2007) found a negative relationship to flow knowledge to customers on innovative performance, particularly with regard to innovation in the product, and the market. The results of testing the last group of hypothesis show that there is a positive and significant effects of sharing knowledge internally on process, product and service innovation, despite the negative impact of the knowledge leakage on sharing of knowledge internally. The total effect indicate that sharing knowledge internally increase these innovative performance despite the negative effect of knowledge leakage. Thus, hypotheses H3a, H3b are 
not supported. But the results support hypotheses $\mathrm{H} 3 \mathrm{c}$, which indicates knowledge leakage negatively affect the positive impact of internal knowledge on innovation. That leads us to judge that sharing knowledge internally does not support companies to get the desired benefits to achieve innovation in the markets, because that could lead to the loss of important knowledge and reduces the chances of innovation in the market. In contrast, companies should promote sharing of knowledge internally to achieve valuable innovation in the processes and products.

The finding of this study coincide with previous studies in the same field, where the results showed significant and positive direct effects for all kind of knowledge sharing (internally, with consumers, with competitors) within the different levels of significance on innovative performance. The study also showed that there is no negative effects of knowledge leakage on the positive impact of sharing knowledge with customers and competitors on innovation in the market. Based on these results, we suggest companies should allow the exchange of knowledge with customers and competitors in order to develop their creativity and innovation in the markets, and establish clear lines to control this exchange. These finding cope with the study of Teec (2006), he argued that the organizations will not be able to achieve the benefits of its strategy if did not participate knowledge externally, and also will lose access to external knowledge. He stated that despite the fact that companies may refrain from knowledge sharing externally because of the potential risks for leakage of knowledge, but that may lead to an advantage of achieving innovation in performance at the operational level, so the strong competition in the knowledge markets push companies to share knowledge externally. According to product and service innovation, the indirect finding indicated that knowledge leakage negatively effects the positive impact of knowledge sharing (internally, with consumers, with competitors) on innovation in products and services, but the great affect is when sharing knowledge with competitors. Finally, results support hypothesis which indicated knowledge leakage negatively mediate the impact of knowledge sharing with customer, competitors on process innovation $(\mathrm{H} 3 \mathrm{~d}, \mathrm{H} 3 \mathrm{~g})$, and negatively mediate impact of knowledge sharing with competitors on product and service innovation $(\mathrm{H} 3 \mathrm{~h})$, and finally, negatively mediate the impact of internal knowledge sharing on market innovation $(\mathrm{H} 3 \mathrm{c})$. All of these hypothesis were significantly supported. Many researcher agreed upon these finding, (e.g. Martinez-Noya et al., 2013; Casimir et al., 2012; Ahmad et al, 2014; Ritala et al.2015).

\subsection{Theoretical Implication}

Our findings support arguments in the previous studies about the benefits of knowledge sharing on innovative performance. During sharing of knowledge, firms must be aware of risks of knowledge leakage, especially the critical knowledge to outside parties. While the focus of many previous studies were on the negative impact of the knowledge leakage and the need to protect critical knowledge from infusion, the study results indicated that some of these critical knowledge can leak without having a negative impact. In contrast, it is considered necessary in order to access the necessary knowledge to develop innovation abilities. Also, The study did not contradict with previous studies regarding the positive impact of knowledge sharing on innovative performance, but rather complement them. The study also indicated the negative effects of knowledge leakage. Despite the existence of studies in the field of knowledge leakage, few empirical studies have shown knowledge leakage as mediate variable leads to minimize the positive results of knowledge sharing on innovative performance. Ritla et al. (2015) studied knowledge sharing and leakage and their impact on relative innovation performance. He studied the types of knowledge leakage (accidental and intentional). This study is based on the general conceptual framework of knowledge leakage in the study of Ritla et al. (2015), and developed a measure for knowledge sharing internally and externally, knowledge leakage, and innovation performance and tested them empirically.

\subsection{Managerial and Practical Implication}

This study provides an analytical framework about important aspects of knowledge sharing, aspects of knowledge leakage and how they negatively impact innovation performance. This framework provides an opportunity for managers to identify those aspects that could contribute to the promotion of knowledge-sharing activities either internally, or knowledge that can be exchanged with external parties such as customers and competitors. The results of this study could be considered as a guide for people responsible of organizing collaboration and sharing of knowledge, where they can identify aspects of knowledge sharing which can bring benefits, and which aspects of knowledge that can be shared with external parties. This analytical framework may help managers to realize the areas of knowledge sharing activities that could lead to a leak of knowledge. As well as aspects of knowledge leakage that could lead to positive results. Our framework may help managers to map the impact of knowledge leakage, which allow to identify and isolate the knowledge leakage activities and practices that brings harm and problems. The method and measures proposed by this study allow organizations 
to formalize and measure their knowledge sharing activities, the model can be applied on the corporate level to identify the specific impact among organizational units and company's networks, also consider this as an area for empirical future research. The study proposes a theory that may be used to measure the impact of deferent knowledge leakage types on performance.

\subsection{Limitations and Future Research}

This study focused on the effect of knowledge sharing and leakage internally, sharing and leakage knowledge with customers, knowledge sharing with competitors as external parties on innovative performance. Also it focused on the negative impact of knowledge leakage on the positive aspects knowledge sharing. There are many external parties that may deal with the company, not limited to customers and competitors. We indicated during the study to those parties who the company can share knowledge with them (customers, suppliers, competitors, universities, and independent expert). we focused on two of these potential sources of knowledge, customers and competitors because they relate directly to innovative performance in products, processes, and market. Additionally, The study focused on three types of innovative performance, which are innovation in processes, innovation in products and services, and innovation in the market. Other many aspects of innovation have not been touched, as well as other kinds of performance. Other limitations that the results were within a confined geographical location area. Where we obtain responses to the questionnaire from companies in Saudi Arabia only. Ritala, (2015) has indicated that businesses and knowledge sharing culture may be deferent in other countries, Kingdom of Saudi Arabia's economy considered one a strongest economies, oil revolution brought significant growth in manufacturing. KSA recently began the transition to knowledge economy, where much of knowledge sharing occurs dramatically. Enhancing knowledge sharing can improve companies capabilities, but there are concerns about knowledge leakage. Much of knowledge are shared between companies within service sectors, this sector also not included in the study.

This study provides suggestions for future research. Future research should be directed to focus on the other external parties that share knowledge and to measure its impact on different aspects of performance. With regard to performance, we should go for future research to examine the different types of performance, competitive advantage, strategic location, strategic performance, financial performance, operational performance, etc. and measure the effects of knowledge leakage on them. Future studies should be directed to other sectors, such as services sectors, which include industries such as technology, banking and other sectors. Future studies should also be directed to different cultures, as we have said, the exchange of knowledge is influenced by different cultures. Our measurement in knowledge sharing and leakage should be further developed, for example, the measurement should include deferent types of knowledge leakage, assessing knowledge leakage should also focus on the resources of leakage. One of the most resources of leakage is people. Future researches should empirically focus on the motivations for leaking knowledge to other parties. Further researches should focus on the relationships between internal and external knowledge sharing, and how internal knowledge sharing facilitate sharing knowledge with external parties. Finally, the study adopted a measure to examine the relationships between variables at the corporate level, and how knowledge leakage may effects innovative performance. Future studies should be directed to study the wide and overall impact of knowledge leakage the entire supply chain, and how it can also affect the supply chain performance.

\section{Conclusion}

Sharing knowledge internally and externally can bring many benefits to the organization, those related to the development of innovative performance in particular. But the organization may face many risks to this exchange, so-called knowledge leakage. We directly examine the impact of knowledge sharing on innovative performance, also we tested the mediator effects of knowledge leakage on innovation performance. Our results indicated the positive effects of knowledge sharing on innovative performance, negative effects of knowledge leakage on minimizing the positive impact of knowledge sharing on innovation performance. Our finding also indicated that some of knowledge leakage may be beneficial to companies and may have a positive impact, especially when sharing knowledge with customers and competitors in order to develop market innovation. The results provide much and deep understanding of the relationships between internal knowledge sharing, external knowledge sharing, knowledge leakage, and innovation performance. Based on our results, we suggest that companies should focus on aspects of knowledge that can be exchanged, especially with external parties. As well as companies must realize that there are positive aspects for the knowledge leakage that should also focus on.

\section{References}

Ahmad, A., Bosua, R., \& Scheepers, R. (2014). Protecting organizational competitive advantage: Aknowledge leakage perspective. Comput. Secur., 42, 27-39. https://doi.org/10.1016/j.cose.2014.01.001 
Ali, A., Krapfel, R. Jr., \& Labahn, D. (1995). Product innovativeness and entry strategy: Impact on cycle time and break-even time. The Journal of Product Innovation Management, 12(1), 54-70. https://doi.org/10.1016/0737-6782(94)00027-D

Al-Tit, A. (2016a). Management Information Systems in Public Institutions in Jordan: An Eye on Implementation Success Factors and their Relationship with Organizational Performance. International Journal of Advanced Computer Science and Applications, 7(7), 457-463.

Al-Tit, A. (2016b). The Mediating Role of Knowledge Management and the Moderating Part of Organizational Culture between HRM Practices and Organizational Performance. International Business Research, 9(1), 43-54. https://doi.org/10.5539/ibr.v9n1p43

Anderson, J., \& Gerbing, W. (1988). Structural equation modelling in practice: A review and recommended two stage approach. Psychological Bulletin, 27(1), 5-24.

Andrews, J., \& Smith, D. C. (1996, May). In Search of Marketing Imagination: Factors Affecting the Creativity of Marketing Programs for Mature Products. Journal of Marketing Research, 33, 17-37. https://doi.org/10.2307/3152145

Argote, L., Ingram, P., Levine, J. M., \& Moreland, R. L. (2000). Knowledge Transfer in Organizations. Organizational Behavior and Human Decision Processes, 82(1), 1-8. https://doi.org/10.1006/obhd.2000.2883

Avlonitis, G. J., Kouremenos, A., \& Tzokas, N. (1994). Assessing the Innovativeness of Organizations and Its Antecedents: Project Innovstrat. European Journal of Marketing, 28(11), 5-28. https://doi.org/10.1108/03090569410075812

Barachini, F. (2009). Cultural and social issues for knowledge sharing. J. Knowl. Manag., 13(1), 98-110. https://doi.org/10.1108/13673270910931198

Belderbos, R., Carree, M., \& Lokshin, B. (2004). Cooperative R\&D and Firm Performance. Research Policy, 33, 1477-92. https://doi.org/10.1016/j.respol.2004.07.003

Belderbos, R., Carree, M., Diederen, B., Lokshin, B., \& Veugelers, R. (2004). Heterogeneity in R\&D Cooperation Strategies. International Journal of Industrial Organization, 22, 1237-63. https://doi.org/10.1016/j.jindorg.2004.08.001

Bonner, J. M., \& Walker, O. C. (2004). Selecting Influential Business-to-Business Customers in New Product Development: Relational Embeddedness and Knowledge Heterogeneity Considerations. Journal of Product Innovation Management, 21, 155-169. https://doi.org/10.1111/j.0737-6782.2004.00067.x

Byrd, T. A., \& Turner, D. E. (2000). Measuring the flexibility of information technology infrastructure: Exploratory analysis of a construct. Journal of Management Information Systems, 17(1), 167-208.

Byrne, B. (2001). Structural Equation Modeling with AMOS. Lawrence Erlbaum Associate. New Jersey, U.S.A.

Casimir, G., Lee, K., \& Loon, M. (2012). Knowledge sharing influences of trust, commitment and cost. J. Knowl. Manag., 16(5), 740-753. https://doi.org/10.1108/13673271211262781

Cassiman, B., \& Veugelers, R. (2002). R\&D Cooperation and Spillovers: Some Empirical Evidence from Belgium. American Economic Review, 92, 1169-84. https://doi.org/10.1257/00028280260344704

Chesbrough, H. (2003). The era of open innovation. MIT Sloan Management Review, 44(3), 35-41.

Chesbrough, H. (2007). Why Companies Should Have Open Business Models. MIT Sloan Management Review, 48(2).

Choi, S. Y., Lee, H., \& Yoo, Y. (2010). The impact of information technology and transactive memory systems on knowledge sharing, application and team performance: a field study. MIS Quarterly, 34, 855-870.

Christensen, C. M., \& Bower, J. L. (1996). Customer power, strategic investment, and the failure of leading

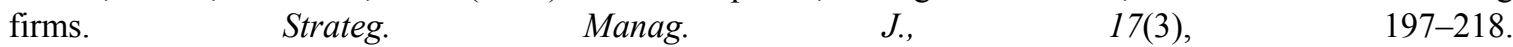
https://doi.org/10.1002/(SICI)1097-0266(199603)17:3<197::AID-SMJ804>3.0.CO;2-U

Cohen, W. M., \& Daniel, A. (1990). Levinthal Absorptive Capacity: A New Perspective on Learning and Innovation Administrative Science Quarterly, Vol. 35, No. 1, Special Issue: Technology, Organizations, and Innovation. pp. 128-152.

Cooper, A. C. (1973). Technical Entrepreneurship: What do We Know? Research and Development Management, 3, 59-64. https://doi.org/10.1111/j.1467-9310.1973.tb01002.x 
Danneels, E., \& Kleinschmidt, E. J. (2001). Product Innovativeness From the Firm's Perspective: Its Dimensions and Their Relation with Product Selection and Performance. The Journal of Product Innovation Management, 18, 357-373. https://doi.org/10.1016/S0737-6782(01)00109-6

Dhanaraj, C., \& Parkhe, A. (2006). Orchestrating innovation networks. Academy of Management Review, 31(3), 659-669. https://doi.org/10.5465/AMR.2006.21318923

Ding, X.-H., Liu, H., \& Song, Y. (2013). Areinternal knowledge transferstrategies double-edged swords? J. Knowl. Manag., 17(1), 69-86. https://doi.org/10.1108/13673271311300769

Duysters, G. M., \& Lokshin, B. (2011). Determinants of alliance portfolio complexity and its effect on innovative performance of companies. J. Prod. Innov. Manag., 28(4), 570-585. https://doi.org/10.1111/j.1540-5885.2011.00824.

Faems, D., Van Looy, B., \& Debackere, K. (2005). Interorganizational Collaboration and Innovation: Toward a Portfolio Approach. Journal of Product Innovation Management, 22, 238-50. https://doi.org/10.1111/j.0737-6782.2005.00120.x

Faisal, M. N., Banwet, D. K., \& Shankar, R. (2007). Information risks management in supply chains: an assessment and mitigation framework. Journal of Enterprise Information Management, 20(6), 677-699. https://doi.org/10.1108/17410390710830727

Foss, N. J., Husted, K., \& Michailova, S. (2010). Governing knowledge sharing in organizations: levels of analysis, governance mechanisms, and research directions. J. Manag. Stud., 47(3), 455-482. https://doi.org/10.1111/j.1467-6486.2009.00870.x

Freel, M. S. (2003). Sectoral Patterns of Small Firm Innovation, Networking and Proximity. Research Policy, 32, 751-70. https://doi.org/10.1016/S0048-7333(02)00084-7

Gupta, A. K., \& Govindarajan, V. (2000). Knowledge Flows within the Multinational Corporation. Strategic Management Journal, $473-496$. https://doi.org/10.1002/(SICI)1097-0266(200004)21:4<473::AID-SMJ84>3.0.CO;2-I

Gupta, S., \& Polonsky, M. J. (2014). Inter-firm learning and knowledge-sharing in multinational networks: An outsourced organization's perspective. Journal of Business Research, 64(4), 615-622. https://doi.org/10.1016/j.jbusres.2013.02.043

Hair, J. F., Black, W. C., Babin, B. J., \& Anderson, R. E. (2010). Multivariate Data Analysis (7th ed.). Prentice Hall, Upper Saddle River, New Jersey.

Hannah, D. R. (2005). Should I keep asecret? The effects of trade secret protection procedures on employees' obligations to protect trade secrets. Organ. Sci., 16(1), 71-84. https://doi.org/10.1287/orsc.1040.0113

Hardy, C., Phillips, E., \& Lawrence, T. B. (2003). Resources,knowledgeandinfluence: the organizational effects of inter-organizational collaboration. J. Manag. Stud., 40(2), 321-347. https://doi.org/10.1111/1467-6486.00342

Hoecht, A., \& Trott, P. (2006). Outsourcing, information leakage and the risk of losing technology-based competencies. Eur. Bus. Rev., 18(5), 395-412. https://doi.org/10.1108/09555340610686967

Holmes-Smith, P. (2001). Introduction to Structural Equation Modelling using LISREL. Perth, ACSPRI-Winter training program.

Hooff, V. D., \& De Ridder, J. A. (2004). Knowledge sharing in context: the influence of organizational commitment, communication climate and CMC usage on knowledge sharing. Journal of Knowledge Management, 8(6), 117-130. https://doi.org/10.1108/13673270410567675

Huizingh, K. R. E. (2011). Open innovation: state of the art and future perspectives. Technovation, 31(1), $2-9$. https://doi.org/10.1016/j.technovation.2010.10.002

Hurmelinna-Laukkanen, P., \& Olander, H. (2014). Copingwithrivals' absorptive capacity ininnovationactivities. Technovation, 34(1), 3-11. https://doi.org/10.1016/j.technovation.2013.07.005

Husted, K., \& Michailova, S. (2010). Dual allegiance and knowledge sharing in inter-firm R\&D collaborations. Organ. Dyn., 39(1), 37-47. https://doi.org/10.1016/j.orgdyn.2009.10.004

Kitchell, S. (1997). CEO Characteristics and Technological Innovativeness: A Canadian Perspective. Canadian Journal of Administrative Sciences, 14(2), 111-125. https://doi.org/10.1111/j.1936-4490.1997.tb00123.x

Knudsen, M. P. (2007). The Relative Importance of Interfirm Relationships and Knowledge Transfer for New 
Product Development Success. Journal of Product Innovation Management, 24, 117-38. https://doi.org/10.1111/j.1540-5885.2007.00238.x

Kogut, B., \& Zander, U. (1992). Knowledgeofthe firm, combinative capabilities and the replication oftechnology. Organ. Sci., 3(3), 383-397. https://doi.org/10.1287/orsc.3.3.383

Kogut, B., \& Zander, U. (1992). Knowledgeofthe firm, combinative capabilities, and the replication of technology. Organ. Sci., 3(3), 383-397. https://doi.org/10.1287/orsc.3.3.383

Laursen, K., \& Salter, A. (2006). Open for Innovation: The Role of Openness in Explaining Innovation Performance among UK Manufacturing Firms. Strategic Management Journal, 27, 131-50. https://doi.org/10.1002/smj.507

Levitt, B., \& March, J. G. (1988). Organizational learning. Annu. Rev. Sociol., 14, 319-340. https://doi.org/10.1146/annurev.so.14.080188.001535

Lichtenthaler, U. (2011). Open Innovation: Past Research, Current Debates, and Future Directions. Academy of Management Perspectives, 25, 75-93. https://doi.org/10.5465/AMP.2011.59198451

Liebeskind, J. P. (1996). Knowledge, strategy, and the theory of the firm. Strategic Manag. J., 17, 93-107. https://doi.org/10.1002/smj.4250171109

Loof, H., \& Heshmati, A. (2002) Knowledge Capital and Performance Heterogeneity: A Firm- Level Innovation Study. International Journal of Production Economics, 76, 61-85. https://doi.org/10.1016/S0925-5273(01)00147-5

Lyles, M. A., \& Salk, J. E. (1996). Knowledge acquisition from foreign parents in international joint ventures. Journal of International Business Studies, 27(5), 877-904. https://doi.org/10.1057/palgrave.jibs.8490155

Lyon, D., Lumpkin, G., \& Dess, G. (2000). Enhancing Entrepreneurial Orientation Research: Operationalizing and Measuring a Key Strategic Decision Making Process. Journal of Management, 26(5), 1055-1085. https://doi.org/10.1177/014920630002600503

Martinez-Noya, A., Garcia-Canal, E., \& Guillen, M. F. (2013). R\&D outsourcing and the effectiveness of intangible investments: is proprietary core knowledge walking out of the door? J. Manag. Stud., 50(1), 6791. https://doi.org/10.1111/j.1467-6486.2012.01086.x

Miller, D. (1983). The Correlates of Entrepreneurship in Three Types of Firms. Management Science, 29, 770-791. https://doi.org/10.1287/mnsc.29.7.770

Miller, D., \& Friesen, P. H. (1983). Strategy-making and Environment: the Third Link. Strategic Management Journal, 4(3), 221-235. https://doi.org/10.1002/smj.4250040304

Nieto, M. J., \& Santamaria, L. (2007). The Importance of Diverse Collaborative Networks for the Novelty of Product Innovation. Technovation, 27, 367-77. https://doi.org/10.1016/j.technovation.2006.10.001

Nunnally, J. C. (1979). Psychometric Theory (2nd ed.). McGraw-Hill, New York.

Powell, W. W., Koput, K., \& Smith-Doerr, L. (1996). Inter-organizational Collaboration and the Locus of Innovation: Networks of Learning in Biotechnology. Administrative Science Quarterly, 41(1), 116-45. https://doi.org/10.2307/2393988

Primo, M. A. M., \& Amundson, S. D. (2002). An Exploratory Study of the Effects of Supplier Relationships on New Product Development Outcomes. Journal of Operations Management, 20, 33-52. https://doi.org/10.1016/S0272-6963(01)00080-8

Raykov, T., \& Widaman, K. F. (1995). Issues in Structural Equation Modeling Research. Structural Equation Modeling: A Multidisciplinary Journal, 2, 289-318. https://doi.org/10.1080/10705519509540017

Ritala, P., Olander, H., Michailova, S., \& Husted, K. (2015, January). Knowledge sharing, knowledge leaking and relative innovation performance: an empirical study. Technovation, 35, 22-31. https://doi.org/10.1016/j.technovation.2014.07.011

Rosenkopf, L., \& Almeida, P. (2003). Overcoming local search through alliances and mobility. Manag. Sci., 49(6), 751-766. https://doi.org/10.1287/mnsc.49.6.751.16026

Sáenz, J., Aramburu, N., \& Blanco, C. E. (2012). Knowledge sharing and innovation in Spanish and Colombian high-tech firms. J. Knowl. Manag., 16(6), 919-933. https://doi.org/10.1108/13673271211276191

Salomo, S., Steinhoff, F., \& Trommsdorff, V. (2003). Customer Orientation in Innovation Projects and New 
Product Development Success - The Moderating Effect of Product Innovativeness. International Journal of Technology Management, 26, 442-63. https://doi.org/10.1504/IJTM.2003.003417

Schulz, M. (2001). The Uncertain Relevance of Newness: Organizational Learning and Knowledge Flows. Academy of Management Journal, 44(4), 661-81. https://doi.org/10.2307/3069409

Schumpeter, J. A. (1934). Depressions: Can we learn from past experience?

Segarra-Blasco, A., \& Arauzo-Carod, J.-M. (2008). Sources of Innovation and Industry-University Interaction: Evidence from Spanish Firms. Research Policy, 37, 1283-95. https://doi.org/10.1016/j.respol.2008.05.003

Sethi, R., Smith, D. C., \& Park, C. W. (2001). Cross-functional Product Development Teams, Creativity, and the Innovativeness of New Consumer Products. Journal of Marketing Research, 38(1), 73-85. https://doi.org/10.1509/jmkr.38.1.73.18833

Sié, L., \& Yakhlef, A. (2009). Passion and Expertise Knowledge Transfer. Journal of Knowledge Management, 13(4), 175-186. https://doi.org/10.1108/13673270910971914

Simatupang, T. M., \& Sridharan, R. (2002). The collaborative supply chain. International Journal of Logistics Management, 13(1), 15-30. https://doi.org/10.1108/09574090210806333

Spithoven, A., Frantzen, D., \& Clarysse, B. (2010). Heterogeneous firm-level effects of knowledge exchanges on product innovation: differences between dynamic and lagging product innovators. J. Prod. Innov. Manag., 27(3), 362-381. https://doi.org/10.1111/j.1540-5885.2010.00722.x

Steensma, H. K., \& Lyles, M. L. (2000). Explaining IJV survival in a transitional economy through social exchange and knowledge-based perspectives. Strategic Management Journal, 21, 831-851. https://doi.org/10.1002/1097-0266(200008)21:8<831::AID-SMJ123>3.0.CO;2-H

Sureshchandar, G. S., Rajendran, C., \& Anantharaman, R. N. (2002). Determinants of customer-perceived service quality: a confirmatory factor analysis approach. Journal of Services Marketing, 16(1), 9-34. https://doi.org/10.1108/08876040210419398

Tan, K. H., Wong, W. P., \& Chung, L. (2015). Information and knowledge leakage in supply chain. Information Systems Frontiers.

Teece, D. J. (2006). Reflections on profiting from innovation. Research Policy, 35(8), 1131-1146. https://doi.org/10.1016/j.respol.2006.09.009

Tether, B. S. (2002). Who Co-operates for Innovation, and Why: An Empirical Analysis. Research Policy, 31, 947-67. https://doi.org/10.1016/S0048-7333(01)00172-X

Tsai, K. H. (2009). Collaborative Networks and Product Innovation Performance: Toward a Contingency Perspective. Research Policy, 38, 765-78. https://doi.org/10.1016/j.respol.2008.12.012

Tsai, K. H., \& Wang, J. C. (2009). External Technology Sourcing and Innovation Performance in LMT Sectors: An Analysis based on the Taiwanese Technological Innovation Survey. Research Policy, 38, 518-26. https://doi.org/10.1016/j.respol.2008.10.007

Tsai, W. (2001). Knowledge Transfer In Intra-organizational Networks: Effects Of Network Position And Absorptive Capacity On Business Unit Innovation And Performance. Academy of Management Journal, 44, 996-1004. https://doi.org/10.2307/3069443

Tsai, W., \& Ghoshal, S. (1998). Social Capital and Value Creation: The Role of Intra-firm Networks. Academy of Management Journal, 41, 464-476. https://doi.org/10.2307/257085

Urban, G. L., \& Von Hippel, E. (1988). Lead User Analyses for the Development of New Industrial Products. Management Science, 34, 569-82. https://doi.org/10.1287/mnsc.34.5.569

Wang, C. L., \& Ahmed, P. K. (2004). The development and validation of the organisational innovativeness construct using confirmatory factor analysis. European Journal of Innovation Management, 7(4), 303-313. https://doi.org/10.1108/14601060410565056

Wisner, B. (2003). Disaster risk reduction in megacities - Making the most of human and social capital. In A. Kreimer, M. Arnold, \& C. Carlin (Eds.), Building Safer Cities- The Future of Disaster Risk Disaster Management Facility (pp. 181-196). World Bank, Washington, DC.

Zellmer-Bruhn, M. E. (2003). Interruptive events and team knowledge acquisition. Management Sci., 49(4), 514-528. https://doi.org/10.1287/mnsc.49.4.514.14423 
Zhao, X., Xie, J., \& Zhang, W. J. (2002). The impact of information sharing and ordering co- ordination on supply chain performance. Supply Chain Management: An International Journal, 7(1), 24-40. https://doi.org/10.1108/13598540210414364

Zirger, B. J. (1997). The Influence of Development Experience and Product Innovativeness on Product Outcome. Technology Analysis \& Strategic Management, 9(3), 287-297. https://doi.org/10.1080/09537329708524285

\section{Appendix A}

\section{Measurement Scales}

\begin{tabular}{|c|c|c|}
\hline Construct & & Dimension/Item \\
\hline Internal & IKS1 & $\begin{array}{l}\text { The organization promotes exchange of information across the different functions in the core supply chain activites } \\
\text { such as manufacturing, supplies, marketing, accounting, and logistics. }\end{array}$ \\
\hline knowledge & IKS2 & We exchange experiences, skills and tacit knowledge between organizational units within the company \\
\hline & IKS3 & We communicate information that related to our business among all employees within the company. \\
\hline Knowledge & $\mathrm{KSC} 1$ & Employees share information, documents and reports related to development and innovation directly with consumers \\
\hline Sharing with & $\mathrm{KSC} 2$ & Employees share information on ways and methods of work with consumers \\
\hline Customer & $\mathrm{KSC} 3$ & Employees share expertise, skills and tacit knowledge with consumers \\
\hline & KSCO1 & Employees share information in technological development trends with competitors \\
\hline Knowledge & $\mathrm{KSCO} 2$ & Employees share information, documents and reports related to R \& D activities with competitors \\
\hline Sharing with & KSCO3 & Employee exchange ways and methods of work with competitors \\
\hline Competitors & KSCO4 & Employees participate expertise, skills about the methods of working with competitors \\
\hline & KSCO5 & Employees exchange relevant information in the field of company's work with competitors \\
\hline \multirow{13}{*}{$\begin{array}{l}\text { Knowledge } \\
\text { Leakage }\end{array}$} & KL1 & Employees provide information relating to the company's business to the parties involved the company's work \\
\hline & KL2 & Employees provide information relating to the company's business to other parties to serve certain goals \\
\hline & KL3 & Business partners and the other parties provide their information to our company \\
\hline & KL4 & Staff on organizational units provide information for businesses and other parties \\
\hline & KL5 & The company faced problems related to leak / loss information to third parties \\
\hline & KL6 & $\begin{array}{l}\text { The company experienced problems with leakage of information through technology-related events (for example, } \\
\text { hacking databases) }\end{array}$ \\
\hline & KL7 & The company is facing problems with leakage of information by the staff (to get information in an unauthorized \\
\hline & & manner) \\
\hline & KL 8 & The company is facing the loss of information leakage due to collaborative efforts with external parties or business \\
\hline & & partners \\
\hline & KL9 & The company faced a leak of information through the transfer of staff to other organizations \\
\hline & KL10 & There is a big possibility that external parties and business partners benefit from our information leaked \\
\hline & KL11 & There was a lot of turmoil for daily operations of the supply chain activities due to leakage and loss of knowledge \\
\hline \multirow{6}{*}{$\begin{array}{c}\text { Process } \\
\text { Innovation }\end{array}$} & PI1 & We constantly working to improve its business operations \\
\hline & PI2 & Our production methods changing very quickly compared to its competitors \\
\hline & PI3 & During the past five years, our company has developed many new methods of administration \\
\hline & PI4 & We use the latest technology to do business operations \\
\hline & PI5 & The nature of the production processes in the company as new as compared with competitors \\
\hline & PI6 & Our company uses innovative methods to solve problems \\
\hline Product and & PSI1 & Our company often considerd the first company to offer new products and services \\
\hline Service & PSI2 & Consumers often look to our new products and services as unfamiliar \\
\hline
\end{tabular}




\begin{tabular}{|c|c|c|}
\hline Innovation & PSI3 & $\begin{array}{l}\text { Compared with our competitors, the company has more innovative products and services introduced over the past } \\
\text { five years }\end{array}$ \\
\hline & PSI5 & $\begin{array}{l}\text { Compared with our competitors, the company has the highest success rate in new products and services that } \\
\text { introduced to the market } \\
\text { Compared to our competitors, our company is considered the fastest in bringing new products and services to the } \\
\text { market }\end{array}$ \\
\hline & $\begin{array}{l}\text { MI1 } \\
\text { MI2 } \\
\text { MI3 }\end{array}$ & $\begin{array}{l}\text { Compared with our competitors, marketing program of our new products and services are revolutionizing the market. } \\
\text { Our new products and services are deferent from the previous products and services } \\
\text { When we introduce new products and services, we use the latest technology. }\end{array}$ \\
\hline Market & MI4 & Often our products and services are a prime location in the market compared to new competitors \\
\hline Innovation & $\begin{array}{l}\text { MI5 } \\
\text { MI6 }\end{array}$ & $\begin{array}{l}\text { Our company is considered superior in the adoption of technological innovations from those of competitors } \\
\text { Our company considered superior to embrace technological innovations compared with competitors } \\
\text { The Company follows a new form of advertising and promotion is different from that used for current products and } \\
\text { services }\end{array}$ \\
\hline
\end{tabular}

* eliminated items.

\section{Copyrights}

Copyright for this article is retained by the author(s), with first publication rights granted to the journal.

This is an open-access article distributed under the terms and conditions of the Creative Commons Attribution license (http://creativecommons.org/licenses/by/4.0/). 